\title{
Kerangka Pemberantasan Korupsi Di Usa Dan Dampaknya
}

\author{
Ang Prisila Kartin \\ email: kartin@unika.ac.id \\ Program Studi Akuntansi, Fakultas Ekonomi dan Bisnis \\ Universitas Katolik Soegijapranata
}

\begin{abstract}
United States is well-known as a superpower country. Among all the countries in the world United States has the best economic strength, military power, and political power. But it is not in line with the Corruption Perceptions Index which indicates how corrupt their public sectors are seen to be. The rampant corruption in United States happened in both of government sector and the private sector. Some cases that have occurred are the Watergate Scandal, Lockheed Scandal, Enron, WorldCom, and Xerox. Various cases of corruption in the United States indicate that superpower country supported by strong economic, military and political conditions does not necessarily make the cases of corruption / frauds in the country to be disappear. United States needs to make efforts to eradicate corruption in the country to suppress possible corruption cases.

Various efforts made by the United States in the form of law issuance and the establishment of corruption eradication agencies are expected to help overcome the problem of corruption in the world. The United States, as the axis of the world's economy and politics, has caused many countries to be affected by the enactment of anticorruption laws. The global awareness in eradicating corruption is expected to bring a positive climate for the global economy to realize a prosperous world community

Keyword : Superpower Country, Corruption Perceptions Index, Fraud, Anti-Corruption Laws
\end{abstract}

\section{LATAR BELAKANG}

Amerika Serikat dikenal sebagai negara adidaya. Dari segi kekuatan ekonomi, GDP tahun 2014 sebesar USD 17,419 triliun membuat Amerika Serikat menjadi negara yang memiliki GDP terbesar di dunia (lampiran 1). Dari sisi kekuatan militer, belanja militer sebesar USD 610 miliar membuat Amerika Serikat menempati posisi 1 dalam besarnya anggaran belanja militer di dunia. Jumlah tersebut hampir tiga kali lipat dari negara yang memiliki anggaran militer kedua terbesar di dunia, bahkan Amerika Serikat menghabiskan lebih dari 
gabungan anggaran pertahanan 15 negara di peringkat berikutnya (lampiran 2). Selain itu dari sisi kekuatan politik, Amerika Serikat juga berhasil mendominasi dan mewakili politik internasional. Hal itu dapat terlihat dari kasus politik luar negeri, Amerika Serikat selalu menjadi prioritas agenda pembicaraan dalam susunan politik internasional. Selain itu dominasi Amerika Serikat di lembagalembaga dunia (World Bank, International Monetary Fund, World Trade Organization) telah membuat kekuatan politik luar negeri Amerika Serikat sangat kuat.

Di lain pihak, Indeks Persepsi Korupsi Amerika Serikat tahun 2015 memiliki skor 76 dimana skor tersebut membuat Amerika Serikat menduduki peringkat 16 negara "terbersih" di dunia. Peringkat ini tentu jauh dari kata adidaya jika dibandingkan dengan kondisi perekonomian, militer, dan politik Amerika Serikat yang menduduki peringkat 1 di dunia (lampiran 3). Amerika Serikat bukanlah negara yang paling "bersih" di dunia, Amerika Serikat justru menjadi salah satu negara munculnya berbagai skandal korupsi / fraud besar di dunia. Korupsi merajalela baik di sektor pemerintahan maupun sektor swasta.

Salah satu skandal korupsi besar di sektor pemerintahan terjadi pada 1972 yang disebut dengan skandal Watergate. Watergate merupakan istilah yang digunakan untuk menggambarkan serangkaian skandal politik di Amerika Serikat yang berujung pada pengunduran diri Presiden Richard Nixon dan mengakibatkan krisis konstitusi yang menghebohkan pada tahun 1970-an. Dalam peristiwa ini terbongkar fakta mengenai korupsi Partai Republik dalam pengumpulan dana pemilihan umum, penyuapan, penyadapan telepon, fitnah yang disebarkan terhadap calon-calon Presiden dari Partai Demokrat, dan praktek kampanye kotor lainnya.

Adapula skandal Lockheed yang terjadi pada kisaran tahun 60 hingga 70an mencuat di media masa Jepang dan Amerika Serikat. Dalam kasus tersebut, Lockheed, salah satu perusahaan pesawat Amerika Serikat, melakukan penyuapan kepada pejabat-pejabat tinggi di Jepang sebagai upaya untuk memenangkan tender pembelian pesawat. Skandal Lockheed mencapai puncaknya ketika 
Perdana Menteri Jepang terbukti menerima suap 500 juta yen dari pejabat tinggi Lockheed. Imbas dari kasus ini adalah mundurnya Perdana Menteri Tanaka dan presiden komisaris Lockheed, Daniel Haughton dari jabatannya

Pada sektor swasta Amerika Serikat, skandal korupsi yang paling menggemparkan dunia adalah kasus Enron. Enron merupakan perusahaan energi Amerika yang berbasis di Houston, Texas, Amerika Serikat. Kasus fraud yang dilakukan oleh Enron adalah kasus yang paling menggemparkan karena kasus ini juga melibatkan Kantor Akuntan Publik yang ternama, yaitu Kantor Akuntan Publik Arthur Andersen. Dalam kasus Enron diketahui terjadinya perilaku moral hazard diantaranya manipulasi laporan keuangan dengan mencatat keuntungan 600 juta Dollar AS padahal perusahaan mengalami kerugian. Manipulasi keuntungan disebabkan keinginan perusahaan agar saham tetap diminati investor.

Kasus serupa skandal Enron dengan modus manipulasi akuntansi pada laporan keuangan perusahaan juga terjadi pada WorldCom dan Xerox. WorldCom, dalam laporan pembukuannya mengumumkan keuntungan sebesar USD 3,8 milyar antara periode Januari 2001 - Maret 2002. Hal tersebut adalah murni rekayasa akuntansi keuangan. WorldCom memasukan USD 3,8 milyar yang merupakan biaya operasi normal ke dalam pos investasi. Hal ini memungkinkan perusahaan tersebut menekan biaya selama bertahun-tahun. Dengan hilangnya pos biaya operasional ini, maka pos keuntungan menjadi lebih besar karena biaya yang seharusnya mengurangi keuntungan sudah diperkecil. Dengan keuntungan yang terlihat besar, maka akan menunjukkan bahwa kinerja WorldCom sangat bagus

Xerox Corporation melakukan berbagai kesalahan pencatatan accounting dalam keuangan mereka. Terungkap pelanggaran terhadap GAAP yang menaikkan pengakuan pendapatan perusahaan secara berlipat melebihi US\$ 3 miliar daripada nilai yang sebenarnya, dan pada akhirnya menaikkan pendapatan sebelum kena pajak senilai lebih dari US\$ 1,5 miliar. Hal ini dilakukan perusahaan Xerox Corp bertujuan untuk memenuhi standar pasar saham Wall 
Street sehingga menyamarkan kinerja operasi perusahaan yang sebenarnya dari para investor. Dalam laporan revisi kepada Security And Exchange Commision dilaporkan bahwa selama periode tahun 1997 hingga 2001 Xerox Corp mencatat kelebihan penjualan peralatan senilai US\$ 6,4 miliar.

Beberapa kasus korupsi lain terjadi tidak hanya di dalam negara Amerika Serikat namun juga terjadi lintas negara, diantaranya : mantan eksekutif Walmart de Meksiko diduga pada bulan September 2005 telah membayar suap kepada pejabat di seluruh Meksiko untuk mendapatkan izin konstruksi; William J. Jefferson, mantan wakil Demokrat dari Louisiana, menyuap pemerintah Afrika untuk kepentingan bisnis; Perusahaan Hewlett Packard membayar sekitar USD 10.900.000 uang suap antara 2004 dan 2006 kepada Jaksa Agung Rusia untuk memenangkan kontrak $€ 35.000 .000$ dolar untuk memasok peralatan komputer di seluruh Rusia; Antara 1995 dan 2004, perusahaan patungan TKSJ, yang terdiri Technip SA, Snamprogetti Belanda BV, Kellogg Brown and Root Inc (KBR), dan JGC Corporation memenangkan empat kontrak di Nigeria senilai lebih dari USD 6 miliar sebagai akibat langsung dari pembayaran USD 51 juta kepada Marubeni yang akan digunakan untuk menyuap pejabat pemerintah Nigeria.

Berbagai kasus korupsi yang terjadi di Amerika Serikat mengindikasikan bahwa kekuatan negara adidaya yang didukung oleh kondisi perekonomian, militer, dan politik yang kuat tidak serta merta membuat kasus korupsi / fraud di negara tersebut hilang. Amerika Serikat masih perlu untuk melakukan berbagai upaya pemberantasan korupsi di negaranya untuk menekan kasus korupsi yang mungkin terjadi.

\section{KERANGKA TEORI}

Korupsi merupakan perbuatan yang bertentangan dengan kaidah-kaidah umum yang berlaku di masyarakat. Kata "korupsi" berasal dari bahasa Latin "corruptio" atau "corruptus". Selanjutnya dikatakan bahwa "corruptio" berasal dari kata "corrumpere", suatu bahasa Latin yang lebih tua. Dari bahasa Latin tersebut kemudian dikenal istilah "corruption, corrupt" (Inggris), 
“corruption" (Perancis) dan "corruptie/korruptie" (Belanda). Arti kata korupsi secara harfiah adalah kebusukan, keburukan, kebejatan, ketidakjujuran, dapat disuap, tidak bermoral, penyimpangan dari kesucian.

Ada 3 hal yang mendorong terjadinya sebuah upaya fraud, yaitu pressure (dorongan), opportunity (peluang), dan rationalization (rasionalisasi), sebagaimana tergambar berikut ini:

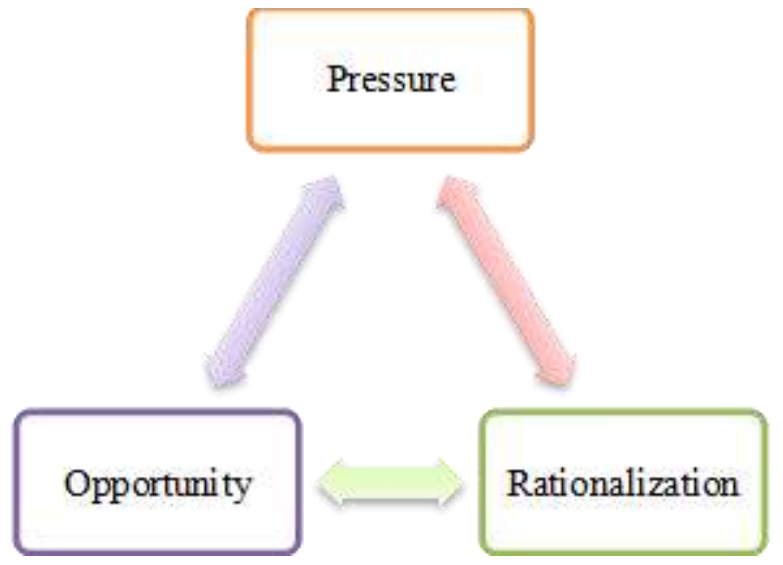

- Pressure adalah dorongan yang menyebabkan seseorang melakukan fraud, contohnya hutang atau tagihan yang menumpuk, gaya hidup mewah, ketergantungan narkoba, dll. Pada umumnya yang mendorong terjadinya fraud adalah kebutuhan atau masalah finansial. Tapi banyak juga yang hanya terdorong oleh keserakahan.

- Opportunity adalah peluang yang memungkinkan fraud terjadi. Biasanya disebabkan karena internal control suatu organisasi yang lemah, kurangnya pengawasan, dan/atau penyalahgunaan wewenang. Di antara 3 elemen fraud triangle, opportunity merupakan elemen yang paling memungkinkan untuk diminimalisir melalui penerapan proses, prosedur, dan control dan upaya deteksi dini terhadap fraud.

- Rasionalisasi menjadi elemen penting dalam terjadinya fraud, dimana pelaku mencari pembenaran atas tindakannya, misalnya: 
1. Tindakan fraud dilakukan untuk membahagiakan keluarga dan orangorang yang dicintainya.

2. Masa kerja pelaku cukup lama sehingga dia merasa berhak mendapatkan lebih daripada yang telah dia dapatkan sekarang (posisi, gaji, promosi, dll.)

3. Perusahaan telah mendapatkan keuntungan yang sangat besar dan tidak mengapa jika pelaku mengambil bagian sedikit dari keuntungan tersebut.

Perilaku korupsi menyangkut berbagai hal yang bersifat kompleks. Faktor-faktor penyebabnya bisa dari internal pelaku-pelaku korupsi, tetapi bisa juga bisa berasal dari situasi lingkungan yang kondusif bagi seseorang untuk melakukan korupsi. Dengan demikian secara garis besar penyebab korupsi dapat dikelompokan menjadi dua yaitu faktor internal dan faktor eksternal.

1. Faktor internal, merupakan faktor pendorong korupsi dari dalam diri, yang dapat dirinci menjadi:

a. Aspek Perilaku Individu

- Sifat tamak/rakus manusia. Korupsi bukanlah kejahatan kecilkecilan karena mereka membutuhkan makan. Korupsi adalah kejahatan orang profesional yang rakus. Sudah berkecukupan, tapi serakah. Mempunyai hasrat besar untuk memperkaya diri. Unsur penyebab korupsi pada pelaku semacam itu datang dari dalam diri sendiri, yaitu sifat tamak dan rakus.

- Moral yang kurang kuat. Seorang yang moralnya tidak kuat cenderung mudah tergoda untuk melakukan korupsi. Godaan itu bisa berasal dari atasan, teman setingkat, bawahannya, atau pihak yang lain yang memberi kesempatan untuk itu.

- Gaya hidup yang konsumtif. Kehidupan di kota-kota besar sering mendorong gaya hidup seseorang menjadi konsumtif. Namun bila perilaku konsumtif tersebut tidak diimbangi dengan pendapatan yang memadai maka akan membuka peluang seseorang untuk melakukan 
berbagai tindakan untuk memenuhi hajatnya. Salah satu kemungkinan tindakan itu adalah dengan korupsi.

b. Aspek Sosial

Perilaku korup dapat terjadi karena dorongan keluarga. Kaum behavioris mengatakan bahwa lingkungan keluargalah yang secara kuat memberikan dorongan bagi orang untuk korupsi dan mengalahkan sifat baik seseorang yang sudah menjadi ciri khas pribadinya. Lingkungan yang dimaksud dalam hal ini cenderung memberikan dorongan dan bukan memberikan hukuman pada seseorang ketika ia menyalahgunakan kekuasaannya.

2. Faktor eksternal, merupakan pemicu perilaku korupsi yang disebabkan oleh faktor di luar diri pelaku.

a. Aspek sikap masyarakat terhadap korupsi

Pada umumnya jajaran manajemen selalu menutupi tindak korupsi yang dilakukan oleh segelintir oknum dalam organisasi. Akibat sifat tertutup ini pelanggaran korupsi justru terus berjalan dengan berbagai bentuk. Berikut ini adalah beberapa sikap masyarakat yang berpotensi menyuburkan tindak korupsi terjadi :

- Nilai-nilai di masyarakat kondusif untuk terjadinya korupsi. Korupsi bisa ditimbulkan oleh budaya masyarakat. Misalnya, masyarakat menghargai seseorang karena kekayaan yang dimilikinya. Sikap ini seringkali membuat masyarakat tidak kritis pada kondisi, misalnya dari mana kekayaan itu didapatkan.

- Masyarakat kurang menyadari bahwa korban utama korupsi adalah masyarakat sendiri. Anggapan masyarakat umum terhadap peristiwa korupsi, sosok yang paling dirugikan adalah negara. Padahal bila negara merugi, esensinya yang paling rugi adalah masyarakat juga, karena proses anggaran pembangunan bisa berkurang sebagai akibat dari perbuatan korupsi.

- Masyarakat kurang menyadari bila dirinya terlibat korupsi. Setiap perbuatan korupsi pasti melibatkan anggota masyarakat. Hal ini 
kurang disadari oleh masyarakat. Bahkan seringkali masyarakat sudah terbiasa terlibat pada kegiatan korupsi sehari-hari dengan caracara terbuka namun tidak disadari.

- Masyarakat kurang menyadari bahwa korupsi akan bisa dicegah dan diberantas bila masyarakat ikut aktif dalam agenda pencegahan dan pemberantasan. Pada umumnya masyarakat berpandangan bahwa masalah korupsi adalah tanggung jawab pemerintah semata. Masyarakat kurang menyadari bahwa korupsi itu bisa diberantas bila masyarakat turut aktif dalam proses pemberantasan korupsi.

b. Aspek ekonomi

Pendapatan tidak mencukupi kebutuhan. Dalam rentang kehidupan ada kemungkinan seseorang mengalami situasi terdesak dalam hal ekonomi. Keterdesakan itu membuka ruang bagi seseorang untuk mengambil jalan pintas diantaranya dengan melakukan korupsi.

c. Aspek Politis

Kontrol sosial adalah suatu proses yang dilakukan untuk mempengaruhi orang-orang agar bertingkah laku sesuai dengan harapan masyarakat. Kontrol sosial tersebut dijalankan dengan menggerakkan berbagai aktivitas yang melibatkan penggunaan kekuasaan negara sebagai suatu lembaga yang diorganisasikan secara politik melalui lembaga-lembaga yang dibentuknya. Dengan demikian instabilitas politik, kepentingan politis dalam meraih dan mempertahankan kekuasaan sangat potensi menyebabkan perilaku korupsi

d. Aspek Organisasi

- Kurang adanya sikap keteladanan pimpinan. Posisi pemimpin dalam suatu lembaga formal maupun informal mempunyai pengaruh penting bagi bawahannya. Bila pemimpin tidak bisa memberi keteladanan yang baik di hadapan bawahannya, misalnya berbuat korupsi, maka kemungkinan besar bawahnya akan mengambil kesempatan yang sama dengan atasannya. 
- Tidak adanya kultur organisasi yang benar. Kultur organisasi biasanya punya pengaruh kuat terhadap anggotanya. Apabila kultur organisasi tidak dikelola dengan baik, akan menimbulkan berbagai situasi tidak kondusif yang mewarnai kehidupan organisasi. Pada posisi demikian, perbuatan negatif seperti korupsi memiliki peluang untuk terjadi.

- Kurang memadainya sistem akuntabilitas. Institusi pemerintahan umumnya pada satu sisi belum dirumuskan dengan jelas visi dan misi yang diembannya, dan belum dirumuskan tujuan dan sasaran yang harus dicapai dalam periode tertentu guna mencapai hal tersebut. Akibatnya, sulit dilakukan penilaian terhadap instansi pemerintah tersebut apakah instansi tersebut berhasil mencapai sasarannya atau tidak. Akibat lebih lanjut adalah kurangnya perhatian pada efisiensi penggunaan sumber daya yang dimiliki. Keadaan ini memunculkan situasi organisasi yang kondusif untuk praktik korupsi.

- Kelemahan sistim pengendalian manajemen. Pengendalian manajemen merupakan salah satu syarat bagi tindak pelanggaran korupsi dalam sebuah organisasi. Semakin longgar/lemah pengendalian manajemen dalam sebuah organisasi maka akan semakin membuka kesempatan bagi anggota atau pegawai di dalamnya untuk melakukan tindak korupsi.

- Lemahnya pengawasan. Secara umum pengawasan terbagi menjadi dua, yaitu pengawasan internal (pengawasan fungsional dan pengawasan langsung oleh pimpinan) dan pengawasan bersifat eksternal (pengawasan dari legislatif dan masyarakat). Pengawasan ini kurang bisa efektif karena beberapa faktor, diantaranya adanya tumpang tindih pengawasan pada berbagai instansi, kurangnya profesional pengawas serta kurangnya kepatuhan pada etika hukum maupun pemerintahan oleh pengawas sendiri. 


\section{Pembahasan dan Analisis}

Menurut The Fraud Triangle Theory, ada 3 hal yang mendorong terjadinya sebuah upaya fraud, yaitu pressure (dorongan), opportunity (peluang), dan rationalization (rasionalisasi). Selama masih ada faktor-faktor tersebut maka tindakan korupsi akan menjadi tak terhindarkan. Sifat dasar manusia yang tidak pernah puas dengan apa yang telah dimilikinya membuat manusia menjadi serakah dan egois dalam upaya untuk memperoleh sesuatu. Segala cara dapat dilakukan untuk dapat memperoleh kekayaan, kekuatan, dan kekuasaan yang diinginkan. Salah satu cara yang dilakukan adalah dengan melakukan fraud / korupsi. Korupsi disebut-sebut telah menjadi budaya dalam masyarakat, yang kemudian tidak dapat diberantas dengan mudah. Korupsi juga terorganisir dan berakar sangat dalam, sehingga upaya dalam mengentaskan atau menumbangkan korupsi itu menjadi sangat sulit.

Budaya korupsi ini tak terkecuali juga menggerogoti Amerika Serikat. Kekuatan negara adidaya yang didukung oleh kondisi perekonomian, militer, dan politik yang kuat tidak serta merta membuat kasus korupsi / fraud di negara tersebut hilang. Sebaliknya banyak bermunculan skandal fraud yang terjadi baik di bidang pemerintahan maupun di ranah swasta. Posisi Amerika Serikat sebagai poros dunia menyebabkan skandal yang bermunculan di Amerika Serikat akan disorot sangat tajam, skandal yang terjadi di Amerika Serikat dapat berdampak luas pada dunia hingga menyebabkan jalannya perekonomian dan politik menjadi terganggu.

Dampak yang ditimbulkan dari korupsi ini dapat menyentuh berbagai segi kehidupan dari suatu bangsa dan negara di dunia ini. Korupsi menjadi masalah yang sangat serius karena dapat membahayakan pembangunan sosial ekonomi, dan juga politik, serta dapat merusak moral bangsa dan sendi-sendi kehidupan dari suatu bangsa. Beberapa dampak yang dapat ditimbulkan dari korupsi adalah :

- Berkurangnya kepercayaan masyarakat terhadap pemerintah. Apabila pejabat pemerintah melakukan korupsi maka akan mengakibatkan berkurangnya 
kepercayaan terhadap pemerintah tersebut. Di samping itu negara lain juga lebih mempercayai negara yang pejabatnya bersih dari korupsi, baik dalam kerjasama di bidang politik, ekonomi, ataupun dalam bidang lainnya. Hal ini akan mengakibatkan pembangunan di segala bidang akan terhambat khususnya pembangunan ekonomi serta mengganggu stabilitas perekonomian negara dan stabiloitas politik.

- Berkurangnya kewibawaan pemerintah dalam masyarakat. Apabila banyak dari pejabat pemerintah yang melakukan penyelewengan keuangan negara, masyarakat akan bersikap apatis terhadap segala anjuran denqan tindakan pemerintah. Sifat apatis masyarakat tersebut mengakibatkan ketahanan nasional akan rapuh dan mengganggu stabilitas keamanan negara.

- Menyusutnya pendapatan negara. Penerimaan negara untuk pembangunan didapatkan dari dua sektor, yaitu dari pungutan bea dan penerimaan pajak. Pendapatan negara dapat berkurang apabila tidak diselamatkan dari penyelundupamn dan penyelewengan oleh oknum pejabat pemerintah pada sektor-sektor penerimaan negara tersebut.

- Rapuhnya keamanan dan ketahanan negara. Keamanan dan ketahanan negara akan menjadi rapuh apabila para pejabat pemerintah mudah disuap. Pengaruh korupsi juga dapat mengakibatkan berkurangnya loyalityas masyarakat terhadap negara.

- Perusakan mental pribadi. Seseorang yang sering melakukan penyelewengan dan penyalahgunaan wewenang mentalnya akan menjadi rusak. Hal ini mengakibatkan segala sesuatu dihitung dengan materi dan akan melupakan segala yang menjadi tugasnya serta hanya melakukan tindakan ataupun perbuatan yang bertujuan untuk menguntungkan dirinya atau orang lain yang dekat dengan dirinya.

- Hukum tidak lagi dihormati. Negara kita merupakan negara hukum dimana segala sesuatu harus didasarkan pada hukum. Tanggung jawab dalam hal ini bukan hanya terletak pada penegak hukum saja namun juga pada seluruh warga negara. Cita-cita untuk menggapai tertib hukum tidak akan terwujud 
apabila para penegak hukum melakukan tindakan korupsi sehingga hukum tidak dapat ditegakkan, ditaati serta tidak diindahkan oleh masyarakat.

Upaya pemberantasan korupsi dapat dilakukan dengan menekan faktorfaktor yang mendorong terjadinya korupsi. Upaya tersebut meliputi proses pencegahan, penyelidikan, dan penindakan terhadap pelaku korupsi. Banyaknya skandal fraud yang terjadi di Amerika Serikat membuat U.S. Securities and Exchange Commission (SEC) dan Kongres Amerika Serikat tidak tinggal diam. SEC menerbitkan undang-undang yang mengatur hal terkait korupsi di Amerika Serikat, tertuang dalam Foreign Corrupt Practices Act of 1977 (FCPA) yang merupakan undang-undang hukum federal Amerika Serikat terutama untuk dua ketentuan utama, yang membahas persyaratan transparansi akuntansi berdasarkan Securities Exchange Act of 1934 dan satu lagi tentang penyuapan pejabat asing. Undang-undang tersebut dibuat sebagai hasil tindak lanjut dari investigasi SEC pada pertengahan 1970-an, lebih dari 400 perusahaan Amerika Serikat mengakui melakukan pembayaran yang tidak jelas atau ilegal lebih dari USD 300 juta untuk pejabat luar negeri pemerintah, politisi, dan partai politik. Pelanggaran tersebut mulai dari penyuapan pejabat asing untuk mengamankan beberapa jenis tindakan yang menguntungkan pemerintah asing.

Berbagai skandal akuntansi melibatkan berbagai perusahaan raksasa di Amerika Serikat dan Kantor Akuntan Publik yang terjadi pada tahun 2000an akhirnya melatarbelakangi munculnya Sarbanes-Oxley Act. Sarbanes-Oxley Act adalah nama lain dari undang-undang reformasi perlindungan investor (The Company Accounting Reformand Investor Protection Act of 2002) yang ditandatangani George Bush bulan Juli 2002. Tujuan utama dari Undang-Undang ini yaitu untuk meningkatkan pertanggungjawaban keuangan perusahaan publik (good corporate governance) sehingga memperkecil kemungkinan bagi perusahaan atau organisasi untuk melakukan fraud.

Dalam Sarbanes-Oxley Act diatur tentang akuntansi, pengungkapan dan pembaharuan governance yang mensyaratkan adanya pengungkapan yang lebih 
banyak mengenai informasi keuangan, keterangan tentang hasil-hasil yang dicapai manajemen, kode etik bagi pejabat di bidang keuangan, pembatasan kompensasi eksekutif, dan pembentukan komite audit yang independen. Dalam hal pelaporan, Sarbanes-Oxley Act mewajibkan semua perusahaan publik untuk membuat suatu sistem pelaporan yang memungkinkan bagi pegawai atau pengadu (whistleblowers) untuk melaporkan terjadinya penyimpangan. Dampak atas diberlakukannya Sarbanes-Oxley Act antara lain didirikannya lembaga Public Company Accounting Oversight Board yang melakukan pengawasan bagi kantor akuntan publik dalam melaksanakan tugas audit agar terjamin realibitas dan independensi. Selain itu, Satuan Pengawas Internal merupakan bagian yang wajib ada bagi setiap perusahaan yang tercatat dalam bursa saham dan dalam laporan keuangan yang telah diaudit yang dirilis juga harus menyertakan laporan mengenai pengendalian internal yang dimiliki.

Upaya-upaya pemberantasan korupsi lain yang dilakukan diantaranya dengan diselenggarakannya OCED Bribery Convention yang ditandatangani oleh 34 negara dalam upaya melawan korupsi dimana perjanjian ini mewajibkan untuk memberikan hukuman terkait suap yang dilakukan dalam menjalankan bisnis. OCED Bribery Convention juga mewajibkan para pihak untuk memperbaiki prosedur akuntansi, mencegah adanya off the books accounts demi meminimalkan korupsi. Pengesahan dan pelaksanaan terkait OECD Bribery Convention wajib bagi semua pihak yang menandatangani, semua pihak wajib menerapkan aturan anti korupsi dan hukuman apabila melakukan korupsi, memastikan transparansi terjadi di organisasi pemerintahan, mengembangkan kode etik yang menjunjung tinggi profesionalitas dan integritas, melibatkan kontrol dari masyarakat terhadap pemerintahan dan menjunjung tinggi demokrasi.

Penanganan yang serius perihal korupsi di Amerika Serikat bisa terlihat dari banyaknya organisasi non pemerintah (non-governmental organization) yang juga berpartisipasi dalam upaya pemberantasan korupsi. Organisasi non pemerintah bersama international business community berusaha untuk 
mengkampanyekan anti korupsi dan transparansi. Beberapa organisasi non pemerintah tersebut diantaranya :

- World Trade Organization. Beberapa negara yang tergabung dalam WTO menyetujui perjanjian mutlilateral terkait transparansi dalam prosedur pengadaan barang. Hal ini juga merupakan suatu upaya untuk meminimalkan praktik korupsi yang ada.

- Global Forum Fighting Corruption. Pertama kali didirikan di Amerika Serikat pada Februari 1999. Forum ini diikuti oleh 90 pemerintahan yang setuju untuk menerapkan prinsip dan praktik yang efektif untuk melawan korupsi, serta mempromosikan transparansi dan praktik good governance, dan pengawasan satu terhadap lainnya sebagai bentuk evaluasi. Terdapat beberapa prinsip dasar dalam forum tersebut seperti adanya kode etik dan juga penerapan integritas pada organisasi pemerintahan, adanya kebebasan terhadap media untuk meliput korupsi, adanya public discussion sebagai salah satu pengendalian terhadap korupsi.

- International Financial Institutions. The World Bank, Inter-American Development Bank, dan International Monetary Fund (IMF) telah menentukan korupsi sebagai penghambat pertumbuhan ekonomi dan stabilitas keuangan yang serius dan harus dibahas dalam konteks evaluasi dan program pendukung dari ekonomi dan keuangan. Seluruh bank pembangunan resmi dipimpin oleh World Bank bekerja bersama untuk menyetujui dokumen dan peraturan standar penawaran pembelian demi tercapainya keadilan berkompetisi dan efisiensi penggunaan dana sektor publik

- International Chamber of Commerce. ICC merupakan organisasi bisnis dunia yang mendukung adanya perdagangan dunia yang terbuka disertai dengan sistem investasi dan pasar bebas. ICC membuat model peraturan untuk mengelola pelaksanaan bisnis lintas batas. Pada tahun 1977 ICC menerbitkan "Rules of Conduct to Combat Extortion and Bribery". Peraturan ICC yang mendukung adanya integritas dalam transaksi bisnis diharapkan dapat menjadi metode untuk self-regulation dalam bisnis internasional 
- Transparency International. TI adalah sebuah organisasi advokasi nonprofit yang bekerja untuk membatasi korupsi pada transaksi bisnis internasional dan area lainnya. TI berfungsi sebagai sekretariat atas konferensi dua tahunan bernama IACC (International Anti-Corruption Conference) yang menyatukan praktisi dan akademisi untuk bertukar informasi dan ide mengenai usaha perlawanan korupsi

- Global Corporate Governance Forum. Global Corporate Governance Forum bertujuan untuk mempromosikan dan meningkatkan tata kelola perusahaan pada basis seluruh dunia. GCG merupakan pondasi yang penting untuk pasar bebas yang berfungsi dengan baik, meningkatkan kinerja ekonomi jangka panjang masing-masing negara, dan memperkuat sistem keuangan internasional. Global Corporate Governance Forum menyediakan kerangka dasar untuk kerjasama internasional dan untuk menciptakan sinergi

Upaya lain yang menjadi kunci upaya pemberantasan korupsi di Amerika Serikat adalah adanya peran aktif dari masyarakat sipil. Ciri masyarakat yang bebas adalah adanya kemampuan individu untuk bersekutu dengan warga/perkumpulan/organisasi lain yang sepikiran, menyatakan pendapat, memberikan petisi kepada pemerintah, dan menerima peraturan hukum. Dunia bisnis bersama dengan masyarakat sipil melakukan pencegahan praktek korupsi, memperkuat institusi publik, dan meningkatkan budaya anti korupsi dalam masyarakat.

\section{Kesimpulan}

Sebagai negara adikuasa dalam hal kekuatan ekonomi maupun pemerintah, Amerika Serikat mengalami banyak skandal korupsi baik di lingkungan pemerintah maupun di sektor swasta. Adanya upaya perbaikan sistem, peraturan, dan lembaga-lembaga anti korupsi yang muncul menandakan inisatif yang besar dari pemerintah dan masyarakay untuk dapat melakukan pembenahan berkelanjutan atas penanganan korupsi di Amerika Serikat 
Berbagai upaya yang dilakukan oleh Amerika Serikat dalam bentuk penerbitan Undang-Undang dan pembentukan lembaga pemberantasan korupsi diharapkan dapat turut membantu mengatasi masalah korupsi di dunia. Amerika Serikat yang notabene adalah kiblat dari perekonomian dan politik dunia menyebabkan berbagai negara ikut terkena dampak dari diberlakukannya perundang-undangan anti korupsi oleh Amerika Serikat. Dengan adanya kesadaran global dalam pemberantasan kasus korupsi maka diharapkan dapat membawa iklim yang positif bagi perekonomian global untuk mewujudkan masyarakat dunia yang sejahtera.

\section{DAFTAR PUSTAKA}

Hartanti, Evi. 2005. Tindak Pidana Korupsi. Sinar Grafika. Jakarta.

Hussein, Saddam. 2013. Eksistensi Amerika Serikat Sebagai Kekuatan Global. Global \& Policy Vol. 1, No. 1, Januari - Juni 2013. Hlm 84-91

Olsen, William P. 2010. The Anti-Corruption Handbook. John Wiley \& Sons, Inc. New Jersey

Tim Penulis Buku Pendidikan Anti Korupsi. 2011. Pendidikan Anti - Korupsi Untuk Perguruan Tinggi. Jakarta : Kemendikbud. Kementrian Pendidikan dan Kebudayaan RI Direktorat Jenderal Pendidikan Tinggi

http://data.worldbank.org/indicator/NY.GDP.MKTP.CD?order=wbapi_data_valu e_2014+wbapi_data_value+wbapi_data_value-last\&sort=desc diakses pada tanggal 25 Juni 2016

http://jakartagreater.com/betapa-besarnya-anggaran-militer-amerika-serikat/ diakses pada tanggal 26 Juni 2016

http://www.acfe.com/fraud-triangle.aspx diakses pada tanggal 26 Juni 2016 
JEMAP : Jurnal Ekonomi, Manajemen, Akuntansi dan Perpajakan

ISSN :

http://www.bbc.co.uk/indonesian/news/story/2005/06/050601_watergate.shtml diakses pada tanggal 2 Juli 2016

http://www.kompasiana.com/arif_nurwiyono/korupsi-merupakan-kebudayaan$\underline{\text { dan-naluri-alamiah-manusia 55207c28a33311764646d035 diakses pada }}$ $\underline{\text { tanggal } 4 \text { Juli } 2016}$

http://www.kompasiana.com/betrikaoktaresa/amerika-serikat-negara-yang-tidakadidaya-melawan-korupsi_54f41daa7455139f2b6c8784 diakses pada tanggal 26 Juni 2016

http://www.transparency.org/cpi2015 diakses pada tanggal 24 Juni 2016 
JEMAP : Jurnal Ekonomi, Manajemen, Akuntansi dan Perpajakan

\section{$\underline{\text { Lampiran }}$}

\section{Lampiran 1. GDP Dunia (Sumber : World Bank)}

\begin{tabular}{|c|c|c|c|c|c|}
\hline Country name & $\approx 2011$ & $\div 2012$ & $\approx 2013$ & $\div 2014$ & \\
\hline United States & $15,517,926,000,000$ & $16,163,158,000,000$ & $16,768,053,000,000$ & $17,419,000,000,000$ & \\
\hline China & $7,492,432,097,810$ & $8,461,623,162,714$ & $9,490,602,600,148$ & $10,354,831,729,340$ & \\
\hline Japan & $5,905,632,338,015$ & $5,954,476,603,962$ & $4,919,563,108,373$ & $4,601,461,206,885$ & \\
\hline Germany & $3,757,464,553,795$ & $3,539,615,377,795$ & $3,745,317,149,399$ & $3,868,291,231,824$ & \\
\hline United Kingdom & $2,594,904,662,714$ & $2,630,472,981,170$ & $2,712,296,271,990$ & $2,988,893,283,565$ & \\
\hline France & $2,862,502,085,071$ & $2,681,416,108,537$ & $2,810,249,215,589$ & $2,829,192,039,172$ & \\
\hline Brazil & $2,614,573,170,732$ & $2,460,658,440,428$ & $2,465,773,850,935$ & $2,416,635,506,076$ & \\
\hline Italy & $2,278,089,156,658$ & $2,074,631,555,455$ & $2,133,539,300,230$ & $2,141,161,325,367$ & \\
\hline India & $1,835,814,449,585$ & $1,831,781,515,472$ & $1,861,801,615,478$ & $2,048,517,438,874$ & \\
\hline Russian Federation & $1,904,793,932,483$ & $2,016,112,133,645$ & $2,079,024,782,973$ & $1,860,597,922,763$ & \\
\hline Canada & $1,788,796,361,799$ & $1,832,715,597,432$ & $1,838,964,175,409$ & $1,785,386,649,602$ & \\
\hline Australia & $1,389,919,156,068$ & $1,537,477,830,481$ & $1,563,950,959,270$ & $1,454,675,479,666$ & \\
\hline Korea, Rep. & $1,202,463,682,634$ & $1,222,807,195,712$ & $1,305,604,981,272$ & $1,410,382,988,616$ & \\
\hline Spain & $1,487,924,659,438$ & $1,339,946,773,437$ & $1,369,261,671,179$ & $1,381,342,101,736$ & \\
\hline Mexico & $1,169,362,160,457$ & $1,184,499,844,413$ & $1,258,773,797,056$ & $1,294,689,733,233$ & \\
\hline Indonesia & $892,969,104,530$ & $917,869,913,365$ & $910,478,729,099$ & $888,538,201,025$ & \\
\hline Netherlands & $893,701,695,858$ & $828,946,812,397$ & $864,169,242,953$ & $879,319,321,495$ & 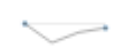 \\
\hline
\end{tabular}


Lampiran 2. Belanja Militer Dunia (Sumber : Bank of America Merrill Lynch)

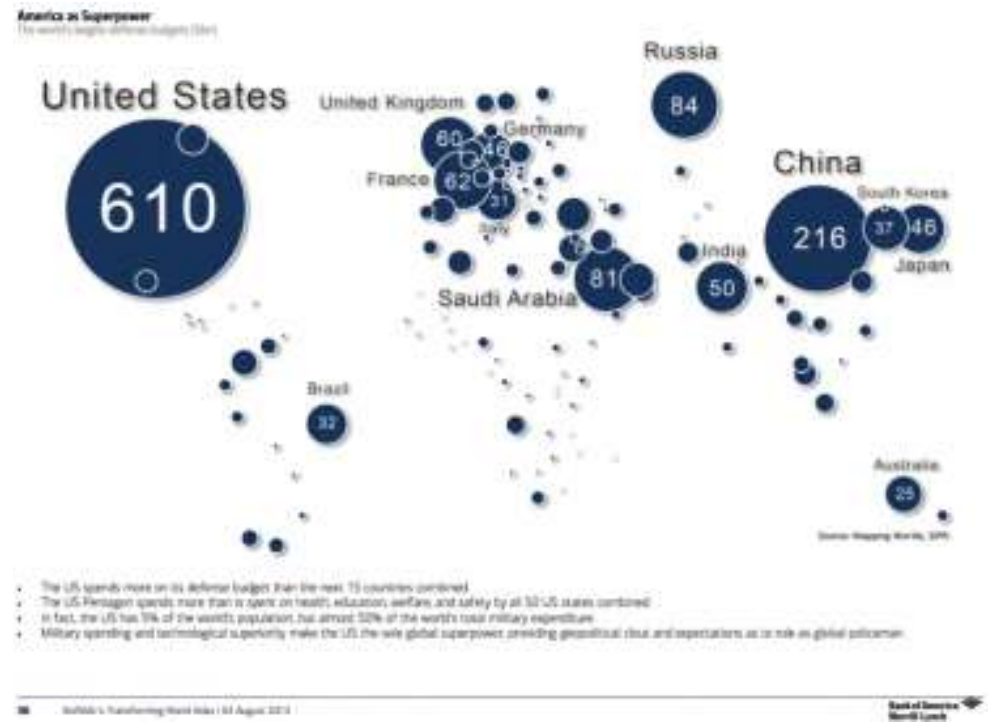

Lampiran 3. Indeks Persepsi Korupsi (Sumber : Data Corruption Perceptions Index 2015) 